\title{
Falando a língua do inimigo: a solidão do missionário nas terras calchaquís
}

\author{
Christophe Giudicelli[1]
}

\begin{abstract}
Resumo
Este trabalho analisou um paradoxo: a sincronia entre a aquisição tardia do idioma kakán pelos missionários e o brutal desaparecimento da missão Calchaquí em meados dos anos 1660. Quando os jesuítas já falavam o idioma, esse conhecimento já não tinha nenhuma utilidade, pela extinção da missão e deportação de seus neófitos. Por sua vez, este paradoxo fez com que o estatuto de tal idioma, hoje inexistente, fosse investigado na economia linguística colonial. De língua veicular, terminou como o idioma exclusivo do inimigo, identificado como um território (os Valles Calchaquies), e como uma atitude rebelde. Sua extensão foi diminuindo conforme a colonização avançava, promovendo-se os idiomas de comunicação colonial, particularmente o quéchua. Por fim, a dispersão dos habitantes fora dos vales deixou aos missionários um conhecimento que serviria apenas para propósitos técnicos: transmitir ordens à milícia dos calchaquíes vencidos, alistados como "índios amigos" nas milícias da província.
\end{abstract}

Palavras-chave: índios calchaquíes, missões de Tucumã, idiomas coloniais.

\section{Hablar la lengua del enemigo: la soledad del misionero en tierras calchaquíes}

\section{Resumen}

Este trabajo analiza una paradoja: la sincronía entre la adquisición tardía del idioma kakán por los misioneros y la brutal desaparición de la misión de Calchaquí, a mediados de los años 1660. Fue precisamente cuando los jesuitas hablaban por fin ese idioma, cuando eso ya no les sería de ninguna utilidad, por la extinción de la misión y deportación de sus neófitos. A su vez, esta paradoja lleva a interrogar el estatuto de ese idioma, hoy desaparecido, en la economía lingüística colonial. De lengua vehicular, terminó siendo lengua exclusiva del enemigo, identificada con un territorio (los Valles Calchaquíes) y una actitud rebelde. Su extensión fue menguando conforme progresaban los idiomas de comunicación colonial - en particular el quechua. Por fin, la dispersión de los habitantes fuera de los Valles dejó a los misioneros un conocimiento que ya sólo les serviría para prestaciones técnicas: para la transmisión de órdenes a los vencidos calchaquíes, alistados como "indios amigos" de la provincia.

Palabras clave: indios calchaquíes, misiones del Tucumán, idiomas coloniales.

\section{Speaking the enemy language: the solitude of the missionary in calchaqui lands}

\section{Abstract}

This paper analyzes the paradoxical simultaneity of the late acquisition of the Kakan language by missionaries and the brutal disappearance of the Calchaqui mission in the mid-1660s. The Jesuits came to master the Indians' language exactly at the time when it stopped being of any use to them, due to the mission's extinction and due to the deportation of its neophytes. This paradox thus calls for further analysis of the status of the now extinct Kakan language within the colonial linguistic economy. The Kakan was a vehicular language and became the enemy's language, associated with a territory (the Calchaquíes valleys) and with a rebellious attitude. Its expansion dwindled over the age of settlement, whose agents promoted the colonial communication languages, and quéchua in particular. Finally, the dispersion of the inhabitants outside the valleys restricted the missionaries' linguistic knowledge to technical use, when they needed to communicate orders to the defeated calchaquíes, then "friendly Indians" in the province militia. Keywords: calchaquíes Indians; Tucumán Province missions; colonial languages.

\section{Parlant la langue de l'ennemi: la solitude du missionnaire chez les Calchaquíes}

\section{Résumé}

Ce travail analyse un paradoxe: la simultanéité entre l'acquisition tardive de la langue kakan par les missionnaires et la disparition brutale de la mission Calchaquí, au milieu des années 1660. Au moment où les jésuites maîtrisaient cette langue, cette connaissance ne devait plus leur être d'aucune utilité, en raison de l'extinction de la mission et de la déportation de leurs néophytes. Ce paradoxe conduit en outre à interroger le statut du kakan dans l'économie linguistique coloniale. De langue véhiculaire, il finit par ne plus que la langue de l'ennemi, identifiée à un territoire (les Vallée Calchaquíes) et une attitude rebelle. Son extension se réduisit au rythme de la promotion des langues de communication coloniale - en particulier le quechua. Enfin, la dispersion des habitants en dehors des Vallées laissa à ces missionnaires une connaissance qui ne leur servit que pour des prestations de service techniques: la transmission des ordres aux vaincus calchaquís désormais «Indiens amis» dans les milices provinciales.

Mots-clés: indiens calchaquís, missions du Tucumán, langues coloniales. 
$\mathrm{E}$ ste breve trabalho procurou analisar um paradoxo: a sincronia entre a aquisição do idioma kakán por parte dos missionários da Companhia de Jesus, depois de décadas de tentativas fracassadas, e o desaparecimento da missão de Calchaquí em meados dos anos 1660.

Foi exatamente quando os jesuítas conseguiram, finalmente, dominar bem a língua dos índios dessa missão que tal conhecimento passou a não ser mais útil para a administração da fé, devido à extinção da missão e à deportação de seus neófitos.

Ao mesmo tempo, isso nos leva a questionar o estatuto desse idioma desaparecido, originalmente falado pelas populações indígenas da área andina de Tucumán, genericamente chamadas de "diaguitas" pelos espanhóis, e logo divididas em "diaguitas", “calchaquies" e "pulares" em função do avanço da frente de conquista e da respectiva posição de cada um desses grupos na economia de vigilância da província. ${ }^{1}$

Vale observar que aquela, que era considerada a "língua geral" de Tucumán no final do século XVI, passou a ser limitada geográfica e simbolicamente ao enclave autónomo calchaquí, que resistiu durante mais de um século a todas as intenções de redução. De língua veicular passou a ser a língua do inimigo, identificada pelo território e atitude rebeldes durante toda a primeira metade do século XVII. Sua extensão regional foi diminuindo na medida em que se estabelecia a colonização espanhola-crioula, cujos agentes promoveram ativamente, por sua vez, os idiomas de comunicação colonial - especialmente o quéchua - nas terras que controlavam.

Nessas condições, os últimos a aprender e praticar o kakán, além de seus falantes naturais, foram os jesuítas, por motivos que remetem à sua atuação na missão de Calchaquí existente entre 1643 e 1658. A guerra que se iniciou em 1658, entre outros motivos, como resultado das manobras de Pedro Bohórquez, “o Inca de Tucumán”, ao causar a dispersão das populações até então autônomas do Vale Calchaquí, causada pela força militar, mudou radicalmente a situação. A dramática deportação dos índios, espalhados em diversas localidades dos quatro cantos do Tucumán e outras regiões mais distantes, deixou esses missionários sem missão com um conhecimento linguístico que somente seria útil para atividades técnicas: particularmente como intérpretes da tropa, transmitindo ordens à milícia dos vencidos calchaquíes que eram parte essencial das tropas dos "índios amigos" da província.

Começaremos pelo final da nossa história. A solidão — anunciada — do último missionário dos chamados calchaquies, o padre Hernando de Torreblanca, que relatou o ocaso dramático de seu trabalho missionário no crepúsculo de sua vida na obra Relación histórica de Calchaquí, escrita em 1696, porém, deixada de lado e inédita até o final do século $\mathrm{XX}^{2}{ }^{2}$

Sobre este assunto, ver Christophe Giudicelli, "Encasillar la frontera. Clasificaciones coloniales y disciplinamiento del espacio en el área diaguito-calchaquí (S. XVI-XVII)", Tandil (Argentina), Anuario IEHS, n. 22, 2007, p. 161-212

2Uma primeira versão foi publicada em 1984, porém, a paleográfica encarregada foi o Archivo General de la Nación (AGN) en 1999. Ambas a cargo de Teresa Piossek Prebisch. Hernando de Torreblanca, Relación Histórica de Calchaquí, Buenos Aires, AGN, 1999. [1696] 
Estamos em meados dos anos 1660. As autoridades coloniais acabam de alcançar, finalmente, o que era uma obsessão e um desafio para o poder espanhol há mais de um século: acabar definitivamente com os índios do Vale de Calchaquí, apoderar-se do desejado corredor valiserrano do Tucumán e forçar seus habitantes a trabalharem nos setores produtivos da província. Após algumas campanhas militares muito difíceis, o governador Alonso de Mercado y Villacorta organizou um processo inédito na zona de desnaturalização sistemática dos habitantes daquele enclave resistente. Um total de 12.000 pessoas, segundo seus cálculos, foi distribuído pelos quatro cantos da província, mas também mais além, até Santa Fé e as margens do Rio da Prata. Um número que não inclui centenas de "peças" divididas entre os soldados que foram parar em diferentes locais do Vice-Reino. ${ }^{3}$

Se as campanhas realizadas por Alonso de Mercado y Villacorta entre o período de 1659 e 1666 não fizeram desaparecer de fato os grupos indígenas da região, ao contrário do que foi divulgado durante muito tempo, ${ }^{4}$ trouxeram, sem dúvida - do ponto de vista do poder colonial - uma solução à "questão calchaqui", ao submeter definitivamente o território autônomo calchaquí à obediência colonial.

O caso é bem conhecido: costuma-se atribuir a responsabilidade deste conflito final às manobras inesperadas de um personagem muito peculiar, chamado Pedro Bohórquez, "o Inca do Tucumán", "Pedro Huallpa,, “branco e loiro", ${ }^{6}$ andaluz de nascimento, porém, autodenominado descendente dos soberanos de Cuzco; ex-descobridor fracassado do Paititi, ex-presidiário em Valdívia, precisamente por causa de seus empreendimentos desastrosos no Peru; inventor de canhões descartáveis ${ }^{7}$ e, sobretudo, mentiroso sem igual. ${ }^{8}$ Em um espaço de três anos, tinha conseguido enganar ao mesmo tempo aos índios, aos principais nobres da província, ao próprio governador e, por fim, aos jesuítas. Aos primeiros, prometia acabar com a opressão, com os roubos, com o trabalho escravo e com as exigências dos encomenderos. Aos segundos, pelo contrário, assegurava que não só iria conquistar a submissão dos rebeldes, mas que estes também iriam revelar a ele os segredos das minas de ouro

\footnotetext{
${ }^{3}$ AGN, Colección “Manuscritos relativos a América” de la Biblioteca Nacional, Leg. 181, n. 853. "Real cédula para que a los indios calchaquíes no se les considere esclavos, 20 diciembre 1674".

${ }^{4}$ Rodolfo Cruz, "El fin de la "ociosa libertad". Calchaquíes desnaturalizados a la jurisdicción de San Miguel de Tucumán en la segunda mitad del siglo XVII", in, Ana María Lorandi (comp.), El Tucumán Colonial y Charcas, Buenos Aires, FFyL - UBA, 1997, T. II, p. 215-261; Lorena Rodríguez, Después de las desnaturalizaciones. Transformaciones socio-económicas y étnicas al sur del valle Calchaquí. Santa María, fines siglo XVII-fines del XVIII, Buenos Aires, Editorial Antropofagia, 2008; Christophe Giudicelli, "De la déportation à l'invisibilisation: la "dénaturalisation" des Indiens Calchaquís (Nord-ouest argentin), XVIle-XXle siècle", in dossier "relocalisation et résilience autochtone", Recherches Amérindiennes au Québec 41(2-3), 2011, p. 61-82.

${ }^{5} \mathrm{AGl}$, Charcas 58, segundo cuaderno de los autos de Pedro Bohórquez, "Auto proveído por el gobernador Mercado y Villacorta, 8 de Julio de 1658", F. 53f-57v.

${ }^{6}$ AGI 122 , F 1 f, "Carta del gobernador Alonso de Mercado y Villacorta a la Audiencia de Charcas", 17-09-1657.

${ }^{7} \mathrm{AGI}, 122,1 \mathrm{f}$, "Carta del Padre Juan de León al capitán Francisco de Nieva y Castilla, 24-06-1657".

'Sobre este personagem, ver Teresa Piossek Prebisch, Pedro Bohórquez, El Inca del Tucumán 1656-1659, Catamarca, Magma, 1999; Ana María Lorandi, De quimeras, rebeliones y utopías. La gesta de Pedro Bohorquez, Lima, Pontificia Universidad Católica del Perú, 1997.
} 
e prata que tentavam encontrar em vão desde a fundação da província. ${ }^{9}$ Para os últimos, pintava o quadro ideal de uma evangelização possivelmente sui generis, mas eficaz, algo que nunca tinha sido alcançado apesar das várias décadas de trabalho, e que desesperava até os mais pacientes trabalhadores da Companhia. Diversas Cartas Anuas tinham lamentado, de forma eufemística, o escasso resultado da pregação: em 1612, os padres “[...] colhem ainda poucos frutos [...]"; ${ }^{10}$ em 1635, “[...] os frutos não correspondiam ao cansaço e zelo dos ministros de Deus [...]"; ${ }^{11}$ a de 1641 evocava que "[...] a missão que sempre foi realizada entre eles, não correspondendo o fruto ao trabalho". ${ }^{12}$ Por fim, a carta dos anos 1653 e 1654, imediatamente antes da invasão de Bohórquez, descrevia em termos semelhantes: "[...] esta missão, na qual vivem presos quatro sacerdotes com mais custos de trabalho do que frutos das almas alheias",13 porém, mostrava-se infinitamente mais pessimista contra “[...] os idólatras deste vale [...] que [...] tanto no físico quanto no moral imitam completamente os costumes dos selvagens mais irrepreensíveis". ${ }^{14}$ Além disso, continuou o redator da mesma Carta Anua, pareciam completamente decididos a nunca admitir a boa nova, a ponto de renegar a fé os poucos que se deixaram convencer, “[...] retornando ao vômito que vinha a eles ao lança-los no inferno, e com isso se encontram frustradas todas as ameaças que só convencem os ânimos mais servis". ${ }^{15}$

"Contudo, aflorava-se nítidamente um certo desânimo neste último informe oficial, o vocabulário não se distanciava do que ditava a Jesuitic correctness". Ao contrário, a correspondência pessoal dos missionários que viveram durante muitos anos no Vale de Calchaquí, em San Carlos e Santa Maria, era muito mais severa. O padre Juan de Léon, por exemplo, não fazia rodeios quando se irava contra "[...] umas bestas, malditos delinquentes", em carta enviada ao encomendero Francisco de Nieva y Castilla. Comemorava ainda, em um surto pouco condizente com o tom benévolo e tranquilo das Anuas, que:

[...] o capitão Pedro Calderón fez muito bem ao levá-los no cabresto, e só fez mal por não os levar até o fim do mundo, para que fossem encarcerados em prisões, porque isso seria mais adequado para sua salvação. ${ }^{16}$

\footnotetext{
${ }_{9}^{9} \mathrm{AGl}$, Charcas 58, primer cuaderno de los autos que se seguían contra Pedro Bohorques, FF 4v-5v, “Carta de Pedro Bohorques al capitán Hernando de Pedraza, 21-04-1657”; AGI, 122, 1 f, Carta del Padre Juan de León al capitán Hernando de Pedraza, 24-06-1657.

${ }^{10}$ Anua de 1612, Documentos para la Historia de Argentina, Buenos Aires, Instituto de Investigaciones Históricas Dr. Emilio Ravignani, FFyL, UBA, 1927-1929, T. XIX, p. 515

"Anua de 1635-1637, Documentos para la Historia de Argentina, Buenos Aires, Instituto de Investigaciones Históricas Dr. Emilio Ravignani, FFyL, UBA, 1927-1929, T. XX, p. 401.

${ }^{12}$ Anua de 1641-1643, Cartas Anuas de la Provincia Jesuítica del Paraguay 1641 a 1643, p. 57. O "pouco fruto" foi também mencionado pelo provincial Nicolás de Mastrilli Durán para considerar o primeiro desaparecimento da residencia de Calchaquí em 1623, “Carta al padre Nicolas Durán, Provincial Córdova, 1624”, in Martín María Morales, A mis manos han llegado. Cartas de los P. Generales a la Antigua Provincia del Paraguay, MadridRoma, Universidad Pontificia de Comillas-I.HS.I, 2005, p. 312-313.

${ }^{13}$ Hernando de Torreblanca, Relación Histórica de Calchaquí, Buenos Aires, AGN, 1999. [1696], p. 136.

${ }^{14} / \mathrm{dem}$, Ibidem, p. 137

15/dem, Ibidem, p. 143

${ }^{16} \mathrm{AGI}, 122,1$ f, "Carta del Padre Juan de León al capitán Francisco de Nieva y Castilla, 24-06-1657”.
} 
Para dar mais força a este meio, algo radical e pouco caridoso que preconizava para a salvação desses índios diaguitas, que tinham sido os principais protagonistas da "Grande Rebelião" dos anos 1630-1640, ${ }^{17}$ era a declaração de que "deixá-los em liberdade é como dar uma faca a um louco descontrolado". ${ }^{18}$

Seja como for, desde o princípio os missionários estavam entre os mais fervorosos partidários do peculiar Inca, sem dúvida em parte porque viam, com sua chegada, a possibilidade de alcançar a tão desejada conversão dos índios, e consideravam poder aproveitar a influência que ele tinha alcançado com seus antigos catecúmenos. Dos quatro missionários, padre Juan de León era, sem dúvida, o que mais acreditava em Bohórquez, e o menos prudente na hora de se referir a ele em correspondências, utilizando termos como "nosso amigo, general dom Pedro,"19 "nosso bom amigo" ${ }^{20}$ e inclusive "nosso Inca". ${ }^{21} \mathrm{O}$ que se sabe ao certo é que este padre não parece ter sido o mais esclarecido, se considerarmos os princípios dos catálogos trienais secretos elaborados pela mesma Companhia, ${ }^{22}$ o que explicaria a falta de prudência em suas cartas de maneira que ele pedia que seus destinatários as queimassem. Essas cartas acabaram fazendo parte dos autos judiciais levantados contra Bohórquez. ${ }^{23} \mathrm{O}$ catálogo secreto de 1651 se refere a ele como ingenium mediocre, um judicium exiguum, uma prudentia parva e uma experientia rerum parva, e esta avaliação preocupante foi confirmada em $1656 .{ }^{24}$ Talvez sua opinião furiosa contra os índios tenha sido influenciada pelo fato de ter nascido em Santiago del Estero, em $1617,{ }^{25}$ ou seja, foi criado, se não no ódio, ao menos na desconfiança que todos os espanhóis-crioulos tinham contra os índios diaguitas e calchaquies rebeldes.

Percebe-se que, de maneira geral, seus irmãos de religião, sem dúvida menos exaltados - e mais bem avaliados por seus superiores - tinham seguido as mesmas orientações, utilizando termos mais comedidos, porém, também aprovando as manobras de um personagem tão estranho. O superior da missão, padre Eugenio de Sancho, tinha escrito ao governador neste sentido, ${ }^{26}$ enquanto Hernando de Torreblanca, também crioulo e filho de um encomendero de Córdoba, ${ }^{27}$ tinha atuado em todas as circunstâncias como intermediário bilíngue, defendendo os interesses do excêntrico projeto neo-inca de Bohórquez.

\footnotetext{
${ }^{7}$ Aníbal Montes, "El gran alzamiento diaguita”, Revista del Instituto de Antropología, Universidad del Litoral, Rosario, n. 1, 1961, p. 81-159.

${ }^{18} \mathrm{AGI}, 122,1 \mathrm{f}$, “Carta del Padre Juan de León al capitán Francisco de Nieva y Castilla, 24-06-1657”.

$19 /$ dem, Ibidem.

${ }^{20} \mathrm{AGI}, 122,1$ f, "Carta del Padre Juan de León al capitán Hernando de Pedraza, 24-06-1657".

${ }^{21} / \mathrm{dem}$, Ibidem.

${ }^{22}$ Para um estudo detalhado dos catálogos, e mais, dos missionários da provincia jesuíta do Peru, ver Aliocha Maldavsky, Vocaciones inciertas. Misión y misioneros en la provincia jesuita del Perú en los siglos XVI y XVII, Madrid, CSIC, 2012

${ }^{23} \mathrm{AGI}, 122, \mathrm{~F} 2$ v, “Carta del Padre Juan de León al capitán Francisco de Nieva y Castilla, 24-06-1657”.

${ }^{24}$ Se encuentran en ARSI, Paraquaria 4-1, F 167 et seq y 192 et seq.

${ }^{25}$ Catálogo trienal de 1644, ARSI, Paraquaria 4-1, F. 142 f et seq.

${ }^{26} \mathrm{AGI}$, Charcas 58, Primer cuaderno de los autos que se seguían contra Pedro Bohórquez, FF 3f-3v, "Carta del P. Eugenio de Sancho", 19-04-1657.

${ }^{27}$ Nasceu em Córdoba no dia 13 de setembro de 1613 e era filho de Juan de Torreblanca, encomendero portugués com suspeita de ser judaizante, o que suscitou uma investigação sobre a limpeza de seu sangue. Martín Morales, op. cit., p. 416. Otros datos biográficos en la Carta Anua de 1689-1700, resumida por Carlos Page, "La evangelización jesuita del Valle Calchaquí. Hacia la idealización de un nuevo hábitat jesuíticocalchaqui", Tempo da Ciência, vol. 17, n. 33, $1^{\circ}$ semestre 2010, p. 44 (p. 25-55).
} 


\section{Intérprete e mediador: a voz do Inca}

Para atingir tamanha força de persuasão, dom Pedro Huallpa necessariamente provou possuir grande eloquência, a qual tinha surpreendido - ou deslumbrado - todos os seus interlocutores. Curiosamente, ainda que ele se expressasse em castelhano com os encomenderos, as autoridades civis e os padres da Companhia de Jesus, ele não sabia o kakán - idioma dos índios que o acolheram - como também não se comunicava em quechua, língua do Tawantinsuyu, cuja renascente dinastia afirmava encarnar. Este fato leva à admiração — posterior - do missionário solitário do qual falamos, Hernando de Torreblanca:

[Pedro Bohórquez] tentou causar a rebelião dos índios, para que ele levasse o nome de "Inga": e o que é de se admirar, nesta bagunça e fantasia, é que ele não sabia a língua geral dos Ingas, que é a Quichua, nem aquela do país de Calchaquí, usando somente um intérprete. ${ }^{28}$

Em um espaço de três anos, tinha conseguido
enganar ao mesmo tempo aos índios, aos principais
nobres da província, ao próprio governador e, por
fim, aos jesuitas

É verdade que Torreblanca tinha alguns motivos para ficar admirado com tal paradoxo: como vimos, ele tinha sido um dos missi dominici de Bohórquez, e tinha se empenhado muito para favorecer a instalação do Inca Andaluz em pleno coração do Vale de Calchaquí, em Tolombón, próximo à sua missão, em San Carlos, convencendo-se que tinha sido pouco o governador deixá-lo levar oficialmente o título de "Inca", além de "lugar-tenente geral", chefe de justiça e capitão de guerra no Calchaquí, suas terras e jurisdição. ${ }^{29}$ Torreblanca se expressa aproximadamente 30 anos depois desse fato em um relato que demonstra sincera amargura frente ao que teve de ser chamado de desastre: as coisas tinham ido tão mal que tudo levou ao fim da missão de Calchaquí, ao retorno da guerra e, finalmente, à desnaturalização dos antigos neófitos, o que pronunciava, na ocasião, o fracasso definitivo dos jesuítas.

De fato, era surpreendente: efetivamente, Pedro Bohórquez somente se dirigia aos índios diaguitas por meio de um intérprete, chamado Lorenzo Pisapanaco, ${ }^{30}$ cujo nome indica que ele vinha das imediações de Pomán, já que Pisapanaco era um povoado indígena dominado há bastante tempo, o que pode explicar a familiaridade que ele tinha com o castelhano.

\footnotetext{
28Hernando de Torreblanca, Relación Histórica de Calchaquí, Buenos Aires, AGN, 1999. [1696], p. 83. ${ }^{29} \mathrm{AGI}$ Charcas 58, Acta de la segunda junta celebrada el 07-08-1657 en San Juan Bautista de la Ribera (Pomán), AGI, Charcas 121, Nombramiento otorgado a Pedro Bohorques, San Juan Bautista de la Ribera 08-08-1657. ${ }^{30}$ Torreblanca, op. cit., p. 41
} 
Porém, se observarmos as coisas atenciosamente, percebemos que Lorenzo não era o único intérprete daquela tragicomédia andina. Nas negociações tripartites entre as autoridades espanholas, Bohórquez e os índios, o verdadeiro intérprete plebiscitado em toda parte era o próprio padre Hernando de Torreblanca, presente em todas as reuniões e signatário dos principais documentos que deram poder a Bohórquez, permitindo-o estar oficialmente no Vale, A participação do missionário nas juntas celebradas durante aproximadamente 15 dias, entre 30 de julho e 13 de agosto de 1657, na cidade de Pomán, foi realmente importante:

Foram feitas várias conferências em juntas [...] e me chamaram a maioria delas como intérprete já que, ainda que houvesse línguas que compreendessem, não eram capazes de entender os assuntos, porque também não sabiam a língua espanhola para poder dizer o que era proposta nem tinham conhecimento dos países e populações de Calchaqui. ${ }^{31}$

O bom padre, porém, omitiu uma informação, na sua Relación Histórica, ou seja, que também era portador de um mandato de Bohórquez e dos índios. De fato participou da cerimônia celebrando o momento que Bohórquez entrou nesta cidade, seguido de centenas de índios armados, para se reunir com o governador e com as autoridades de Pomán. ${ }^{32}$

\section{Intérprete e capelão millitar: a voz da pacificação}

Um ano depois, a situação estava completamente diferente. Entendia-se que Bohórquez estava fomentando uma "revolta geral" - e que sua presença permitia a recomposição de uma trama de alianças debilitadas pelas relações coloniais. O fato é que, desde a jurisdição de La Rioja - mais precisamente, o vale dominado de Famatina ${ }^{33}$ - até as reduções dos Pulares, que há muito tempo serviam aos encomenderos de Salta, ${ }^{34}$ circularam alianças que, segundo relatos, chegaram até Casabindo e às imediações de Potosí, ${ }^{35}$ algo que não acontecia há décadas. Obviamente, os jesuítas passaram a ser mal vistos aos olhos de Bohórquez, que os expulsou manu militari, saqueou suas missões ${ }^{36} \mathrm{e}$ deu início às operações de guerra propriamente ditas, com ataques contra o forte de San Bernardo, caminho de

\footnotetext{
${ }^{31}$ Hernando de Torreblanca, Relación Histórica de Calchaquí, Buenos Aires, AGN, 1999. [1696].

32Piossek Prebisch, Pedro Bohórquez, El Inca del Tucumán 1656-1659, Catamarca, Magma, 1999; p. 114 et seq. reproduz vários documentos inéditos sobre esta entrada. Dá até a lista dos caciques presentes no encontro. Idem, Ibidem, p. 109, nota 181 (es una transcripción de AGI, Charcas, 121).

${ }^{33}$ “Carta del Cura de Famatina, D. Juan Gedeón de Guzmán, al señor Maestre de campo Juan Gregorio Basan de Pedraza, Alcalde ordinario de los Santos, 20-04-1658", Pablo Pastells, Historia de la Compañía de Jesús en la provincia del Paraguay, Madrid, Victoriano Suárez, 1912, vol. 2, p. 535-536.

${ }^{34}$ Christophe Giudicelli, "La raya de los pulares. Pouvoir colonial et quadrillage de l'espace social dans le Valle de Calchaqui", In : Jimena Paz Obregón Iturra, Luc Capdevila et Nicolas Richard (eds), Les indiens des frontières coloniales. Amérique australe, XVle au XXe siècle, Rennes, PUR, 2011, p. 27-58, y « Calibay o la tempestad. Debate en torno a un documento de la Salta primitiva », Revista Corpus, Vol 3, n.1, 2013, http://ppct. caicyt.gov.ar/index.php/corpus/article/view/2819/2668

${ }^{35}$ Torreblanca, op. cit., p. 45

${ }^{36} / \mathrm{dem}$, Ibidem, p. 49-53.
} 
Salta, San Miguel de Tucumán, forte de Andalgalá, com o roubo de várias residências e a destruição das minas de Acay, no caminho que levava do Vale de Calchaquí até o altiplano. ${ }^{37}$ Diante do fracasso de sua ofensiva militar, Bohórquez decidiu ir embora de Tucumán, colocando índios e espanhóis frente a frente. ${ }^{38}$



Figura 1. Ruínas da missão de San Carlos de Tucumanahao.

Já desacreditados e privados da visão de uma conversão more incaico, os missionários não tinham opção senão abandonar definitivamente o vale de Calchaquí e se dedicar a outra de suas funções: trabalhar como capelães militares nas tropas

\footnotetext{
${ }^{37}$ Hernando de Torreblanca, Relación Histórica de Calchaquí, Buenos Aires, AGN, 1999. [1696], p. 52-53. ${ }^{38}$ Aceitou uma proposta oficial de indulto, porém, após várias situações, foi levado diretamente a Lima, onde seria posteriormente executado na prisão. Ana María Lorandi, De quimeras, rebeliones y utopías. La gesta de Pedro Bohorquez, Lima, Pontificia Universidad Católica del Perú, 1997, p. 299-311.

${ }^{39} F o t o$ de Juan Bautista Ambrosetti, "Por el Valle Calchaqui", Anales de la Sociedad Científica, XLIV, Buenos Aires, 1897, p. 289-305. Segundo varios autores, San Carlos de Tucumanahao tinha sido a sede da missão de San Carlos, destruída sob a instância de Bohórquez, e seria diferente da primeira missão de San Carlos de Samalamao, onde aconteceu a primeira tentativa missionária. Para uma discussão sobre este ponto, ver María Teresa Iglesias, Luís Capeletti, Fausto Guerrero, María Victoria Massa, y Liliana Zamagna, "Investigaciones preliminares en el sitio San Carlos (Valle Calchaquí, Salta)", Revista Escuela De Historia, vol. 1, n. 6, 2007.
} 
de pacificação, contra seus ex-catecúmenos. ${ }^{40}$ Para esta tarefa, o superior da missão finalizada, Eugenio de Sancho, e o próprio Hernando de Torreblanca, colocaram-se à disposição das autoridades nas ofensivas lançadas no inverno de 1659. O primeiro acompanhou as colunas militares alistadas em La Rioja e em Londres, ${ }^{41}$ enquanto Torreblanca não se separou mais do governador Mercado y Villacorta, que fez dele uma peça-chave para a pacificação. Devido ao bom conhecimento que tinha da língua do inimigo, ele era a pessoa mais indicada para conduzir as negociações e, concretamente, ditar as condições de rendição impostas pelo governador: "Meu trabalho era contínuo, servindo de intérprete para persuadi-los, por ter mais desenvoltura na língua para expressar os inconvenientes de sua dissipação, se eles não saíssem para dar a paz".42

Além disso, como conhecia muito bem os índios, cuja rendição era exigida, por ter vivido mais de 15 anos entre eles, suas competências "culturais" faziam dele um excelente conselheiro militar para encontrar condições que pudessem ser aceitas pelos vencidos, convencendo-os a entregar as armas:

[...] o senhor governador me concedeu uma graça, de que nenhum índio, mesmo que prisioneiro, sofreria o castigo de ter os cabelos cortados, nem seria açoitado ou machucado; e vossa senhoria me concedeu e assim o fez. ${ }^{43}$

Em outras palavras, o ex-missionário passou a ser elemento imprescindível nas forças de pacificação. Teve papel chave na crucial negociação que resultou na mudança dos calchaquíes de Tolombón e Paciocas, que sempre tinham tido um papel central nas guerras anteriores, e trocaram de aliança sob pressão militar, alistando-se como "índios amigos" ao lado das tropas tucumanas contra seus vizinhos, os Quilmes. ${ }^{44}$ Ele também participou ativamente no final da primeira campanha para identificar os grupos vencidos e promover sua desnaturalização.

Entre 1660 e 1664, o governador Mercado y Villacorta teve de deixar a administração de Tucumán para assumir a do Rio da Prata, e por isso o processo drástico de pacificação que tinha começado foi interrompido. Ao final do seu mandato, retornou ao antigo posto, com a missão explícita de terminar o trabalho iniciado cinco anos antes, retirando todos os índios ainda rebelados, especialmente os de Quilmes e do Vale Yocavil. ${ }^{45}$ Entre as primeiras medidas tomadas para preparar esta segunda campanha, Mercado renomeou o jesuíta crioulo e tradutor que havia trazido tantos resultados positivos:

\footnotetext{
${ }^{40}$ Neste caso, é provável que o cuidado que tinham para participar das operaões militares tinha a ver com a consciencia de sua responsabilidade nessa situação, porém, este tipo de participação foi uma constante em todas as operações de pacificação nas "fronteiras" da América Espanhola. Ver, por exemplo, Christophe Giudicelli "Indios amigos y normalización colonial en las fronteras americanas de la Monarquía Católica (Tucumán, Nueva Vizcaya, S. XVI-XVII)", In: José Javier Ruiz Ibáñez (Coord.), Las milicias del rey de España. Sociedad, política e identidad en las Monarquías ibéricas, Madrid, FCE, 2008, p. 349-377.

${ }^{41}$ Hernando de Torreblanca, Relación Histórica de Calchaquí, Buenos Aires, AGN, 1999. [1696], p. 66.

42/dem, Ibidem, p. 71.

${ }^{43} / \mathrm{dem}$, Ibidem.

${ }^{44} /$ dem, Ibidem, p. 70.

${ }^{45}$ Roxana Boixadós, "El fin de las guerras calchaquíes. La desnaturalización de la nación yocavil a La Rioja (1667)", Corpus n. 1, 2011 (en línea). Christophe Giudicelli, "De la déportation à l'invisibilisation: la "dénaturalisation" des Indiens Calchaquís (Nord-ouest argentin), XVIle-XXle siècle", in dossier "relocalisation et résilience autochtone", Recherches Amérindiennes au Québec 41(2-3), 2011.
} 
Prevenido (Alonso de Mercado) no Porto, recebeu as provisões, já que deveria fazer essa conquista para a campanha, o P. Provincial da Companhia deveria fornecer dois padres pelo tempo que fosse necessário, e um deles foi P. Hernando de Torreblanca, por ter atuado ali muitos anos, e ter acompanhado após a rebelião: ser tradutor e ter conhecimento dos índios. ${ }^{46}$

Neste caso, suas competências particulares - "ser tradutor e ter conhecimento dos índios" - não serviriam somente para as negociações de paz, mas também para assumir uma posição que lhe foi designada na cadeia de poder. Era encarregado de traduzir para o kakán as ordens e outras instruções militares transmitidas pelo governador aos contingentes dos índios amigos de Tolombón e Paciocas nas campanhas contra seus antigos aliados. Segundo ele próprio declarou, Torreblanca era o único que podia fazer isso: "Nunca me faltou o que fazer com os índios porque não havia outra língua que no idioma de sua língua os fizesse entender o que era pretendido, e o governador queria que eles executassem" ${ }^{47}$

O domínio da língua dos calchaquíes que se tornaram "amigos" alcançado por este missionário alterou o que seria sua primeira vocação: mesmo que ainda desempenhasse funções espirituais em diversos colégios que tinham a Companhia de Jesus, ${ }^{48}$ continuou também dedicando tempo e energia para as áreas de vigilância e pacificação, quando era mobilizado pelas autoridades. O argumento que sustentou na obra Relación é que ninguém conseguia falar o kakán como ele. E como os grupos calchaquies reinstalados no Vale de Choromoros ${ }^{49}$ tinham se tornado a principal milícia auxiliar contra os índios do Chaco, nos limites orientais cada vez mais tumultuados do Tucumán, não podia negar-se a acompanhá-los em suas expedições, para que a cadeia de poder não fosse interrompida:

Estando em Salta deu ao índio mocobí, no forte de Esteco, e foi necessário socorrer aquela localidade; e a toda pressa acompanhando esta facção; e como os que ajudavam imediatamente eram os Calchaquís, não podiam faltar, tendo de fazê-los compreender o que era ordenado, e fora de seu país não havia quem os pudesse entender. ${ }^{50}$

Cabe um comentário: mesmo que a participação dos padres nas campanhas militares mais ferozes fosse parte integrante de suas atribuições, não somente no cenário americano - neste caso, reconhecem explicitamente "imitar a capelania castrense de Flandres" ${ }^{51}$-, o surpreendente e mais interessante para nós no caso presente é que a tarefa designada para o padre

\footnotetext{
${ }^{46}$ Hernando de Torreblanca, Relación Histórica de Calchaquí, Buenos Aires, AGN, 1999. [1696], p. 85.

${ }^{47}$ Idem, Ibidem, p. 86.

${ }^{48}$ Foi reitor do Colégio de Salta depois das campanhas militares. ARSI, Paraquaria 4-1, F 217 v.

${ }^{49}$ Cristina López de Albornoz, "Las desnaturalizaciones Calchaquíes y sus efectos en las poblaciones trasladadas al Valle de Choromoros", Anuario de estudios americanos, Tomo XLVII, 1990, p. 29-42.

${ }^{50}$ Hernando de Torreblanca, op. cit., p. 71 y 85-86.

51“'Carta Anua del Provincial Simon de Ojeda, años 1658-1680, In: Torreblanca, op. cit., p. 132: “[...] y así fueron despachados para este fin tres de los misioneros que habían estado entre los calchaquíes, imitándose la capellanía castrense de Flandes".
} 
Torreblanca tenha tido natureza mais prática - linguística - do que espiritual e, além disso, que essa tarefa tenha sido designada a ele quase por não haver escolha. Em outras palavras, o que chama a atenção é que o governador, não tinha à disposição ninguém mais que um intérprete, que já tinha avançada idade $^{52}$ para suas campanhas militares, ou que não tenha encontrado ninguém, por exemplo, para escoltar os milhares de índios Quilmes deportados até o porto de Buenos Aires e, mais precisamente, até a redução da Exaltação de Santa Cruz dos Quilmes, que deu origem à atual cidade de Quilmes. ${ }^{53}$ Isso pesou muito para Torreblanca, já que tinha se candidatado a este posto, que lhe foi negado: "os índios foram levados para mais de 200 léguas de distância e levados a reduções com clérigo que nem os entendia nem sabia sua língua." ${ }^{54}$

Ainda considerando que Torreblanca, no fim de sua vida, estava influenciado pela vontade de resistir ao seu papel vergonhoso em meio à ruína da missão de Calchaquí, enfatizando sua exímia capacidade para as línguas ameríndias, concluímos que, simplesmente, não havia ninguém naquele momento em condições de exercer bem o cargo de intérprete do kakán para o castelhano, e vice-versa. Outro fator que confirmaria esta hipótese: sabe-se que Mercado y Villacorta não "gostava muito da Companhia", e por isso é de se supor que sua eleição tenha sido decidida antes de tudo por considerações práticas. Por sua vez, isso nos conduz quase automaticamente a fazer outra pergunta: como é possível que ninguém ou quase ninguém tenha sido capaz de falar este idioma além de seus falantes naturais, ou seja, os próprios diaguitas?

\section{O kakán, "língua geral"}

Uma primeira reflexão nos levaria a pensar que este seria um idioma pouco abrangente e marginal, porém, esta hipótese deve ser abandonada imediatamente por dois motivos. O primeiro é de natureza conjuntural: a extensão das deportações que acabamos de causar - pelo menos 12.000 pessoas, segundo os cálculos do governador ${ }^{55}$ - faz da população que falava kakán a mais importante da região em um momento no qual os grupos indígenas das zonas controladas do Tucumán tinham alcançado seu mais baixo ponto demográfico. O segundo motivo é que, simplesmente, sabe-se que o kakán era, pelo contrário, um idioma extremamente abrangente com a chegada dos colonos espanhóis, sem dúvida falado para além de sua área principal, ou seja, o corredor interandino do Tucumán e parte da planície tucumano-santiagueña. Em 1582, Pedro Sotelo Narváez, em informativo direcionado ao licenciado Cepeda, presidente

\footnotetext{
${ }^{52}$ ARSI, Paraquaria 4-1, F. 117 et seq, según el catálogo trienal del 1631, contaba ya más de 50 años para la segunda campaña de desnaturalizaciones, ya que nació el 13 de septiembre de 1613.

${ }^{53}$ Miguel Angel Palermo y Roxana Boixadós, "Transformaciones en una comunidad desnaturalizada: los Quilmes, del Valle Calchaquí a Buenos Aires”, Anuario del Instituto de Estudios Históricos y Sociales, v. 6, 1991, p. 13-42; Florencia Carlón, “La reducción “Exaltación de la Cruz de los indios Quilmes”: un caso de relocalización étnica en Pampa a fines del siglo XVII", Mundo agrario, vol. 8, n. 15, 2007 (en línea).

${ }^{54}$ Hernando de Torreblanca, Relación Histórica de Calchaquí, Buenos Aires, AGN, 1999. [1696], p. 111.

${ }^{55}$ Antonio Larrouy, Documentos del Archivo de Indias para la historia del Tucumán, vol.1 Santuario de Señora del Valle, T.l, Buenos Aires, 1923, p. 276.
} 
da Audiência de Charcas, apresenta a língua como sendo língua veicular: “[...] falam uma língua que chamam de diaguita, geral entre eles, porém, há outras quatro línguas que se chamam tonocoté, indama, sanavirona e lule. ${ }^{56}$

Pois bem, o fato de um espanhol habituado à realidade do vice-reinado do Peru falar da "língua geral" não é insignificante. Mensura, de certa forma, o status importante e a função desta língua. Contudo, alguns poderiam não confiar na sensibilidade linguística de um mero espadachim desta província distante - o que se sabe ao certo é que os colonos do Tucumán eram mais conhecidos por sua brutalidade do que por seu amor pela arte e pelas letras. É mais improvável questionar a palavra do primeiro missionário mandado embora pela Companhia para a evangelização do Tucumán. Ainda mais porque este era nada menos que um dos jesuítas pioneiros do Peru, Alonso de Barzana, discípulo de Juan de Ávila, o qual chegou ao Peru no mesmo barco que o vice-rei Toledo, em 1569, veterano das primeiras doutrinas da Companhia, Santiago del Cercado, Huarochirí e Juli. Tanto que ele foi exatamente o redator das primeiras gramáticas e livros religiosos escritos em quéchua e aymara, criados na primeira congregação provincial de janeiro de $1576 .{ }^{57}$

Barzana estava entre os mais notáveis linguistas da Companhia, e aparentemente dominava muito bem os principais idiomas indígenas da Bolívia atual, os quais praticou não somente sendo missionário. Ele também os havia ensinado sendo titular da cátedra diocesana de quéchua, aymara e puquina de Potosí desde 1583, um curso descentralizado da Universidade de Lima, que tinha sido instituído em $1580 .^{58}$

Em 1593, ao anunciar a redação de um vocabulário em cinco línguas, escrito em conjunto com seu companheiro, Pedro de Añasco, que tinha como característica o fato de ser mestiço, nascido em Chahapoyas, decreve o kakán da seguinte forma:

[...] a terceira língua deste vocabulário é ainda mais geral que esta [a tonocoté] porque é falada pela maior parte das pessoas que servem a Santiago e todo o vale de Catamarca, assim como aqueles milhares conquistados pelo governador em Londres e todo o vale de Calchaquí, que conquistou nos anos anteriores. ${ }^{59}$

No ano seguinte, confirmaria o caráter geral desta língua:

As línguas mais gerais que os índios desta terra possuem são o caca, tonocoté, sanavirona. O caca é usada por todos os diaguitas

\footnotetext{
56Roberto Levillier, Nueva crónica de la conquista del Tucumán, v. 3, p. 324-332.

${ }^{57}$ Charles O'Neil, Joaquín M. Domínguez, Diccionario histórico de la Compañía de Jesús, Institum historicum, SI \& Universidad Pontificia Comillas, Madrid, 2001, p. 362-363.

${ }^{58}$ Real Cédula para nas cátedras da universidade dos Reis se estabeleça uma língua geral dos índios, para que os sacerdotes que vão administrá-los tenham ciencia desta língua. 23-09-1580 Pablo Pastells, Historia de la Compañía de Jesús de la provincia del Paraguay, Madrid, 1912, p. 20-22 NB : sigue otra del 5-10-1580: "para que la cátedra de lengua general de los indios que se lee en la universidad de los Reyes se instituya en todas las partes de las Indias donde hay Audiencias y Cancillerías Reales (para que los sacerdotes que salgan a las doctrinas hayan cursado en ella)".

59"Carta de Alonso de Barzana al Provincial, 1593, 20-12, In: “Anua de la provincia del Perú", Monumenta Peruana, T.V. Roma, Institutum Historicum Societati lesu, 1970, p. 383, et seq.
} 
e todo o vale de Calchaquí e o vale de Catamarca, assim como grande parte da Nueva Rioja, e quase todos os povos que servem a Santiago, assim como os povoados do rio del Estero, como muitos outros que estão na serra. Esta língua está aguardando a diligência de nossos obreiros, porque há muitos milhares de infiéis que não podem se comunicar com eles. Faz-se arte e vocabulário com esta língua. [...] Quem tiver a sorte de ser apóstolo diaguita, e sabendo bem a língua caca, andará por todos os povos de Nueva Rioja e do vale de Famatina e de Calchaquí, assim como o de Catamarca, e de todas essas nações que nem vi ele dará conta [...] de quantos povos são [.... ${ }^{60}$

Entendia-se que, para Barzana e seus contemporâneos imediatos, tratavase de uma língua extremamente abrangente, e qualificá-la como geral parecia equiparar a língua quéchua para o Peru ao guarani, para o Paraguai e O Rio da Prata ou o náhuatl, para o México central. Portanto, teria sido lógico - e prático - estabelecer alguns mecanismos mais ou menos institucionalizados de interpretação. Deve-se constatar que, pelo contrário, a passagem de um idioma a outro não só deixou de ser fonte de problemas durante todo o período considerado, mas também foi paulatinamente abandonada devido ao uso de outros idiomas de comunicação, especialmente o quéchua, que passou a ser a língua preferencial de comunicação entre as populações indígenas, nas relações de trabalho, na justiça e na administração. Nossa hipótese é que como o kakán era, antes de tudo, a língua do inimigo, seu uso se restringiu progressivamente aos campos especializados - mesmo que com modalidades distintas e complementares - , que remetem tanto ao programa de submissão quanto ao de transformação social que o poder colonial estava implementando: a vigilância e o controle militar, de um lado, e a missão, de outro.

\section{O quéchua, "língua franca"}

Desde o nascimento da província de Tucumán, por motivos que remetem à origem geográfica imediata - peruana - dos colonos e de seus servidores indígenas, o quéchua era visto como o segundo idioma colonial, antes de transformar-se lentamente na primeira língua de comunicação com os indígenas "domésticos", que tiveram de aprendê-la, quando não a conheciam. Como se sabe, existiam ilhas linguísticas de quéchua em algumas parte do Noroeste argentino, especialmente na região de Santiago del Estero. Também é possível que, pontualmente, devido à presença da mitmaquna importada pelos incas em sua região, alguns grupos tenham tido certo conhecimento sobre a língua imperial, além da sua própria ${ }^{61}$ Contudo, não parece ter sido o caso das populações que falavam kakán, que ocupavam uma fronteira aparentemente conflituosa do ex-Tawantinsuyu. Para essas

\footnotetext{
60“Carta del padre Alonco de Barçana al p. Juan Sebastián, provincial 1594, 08-09 (desde Asunción)”, Monumenta Peruana, T.V., Roma, Institutum Historicum Societati lesu, 1970, p. 568-580, et seq.

${ }^{61}$ Ana María Lorandi, "Evidencia en torno a los mitmaqkuna incaicos en el N.O. argentino", Anthropologica, n. 9, diciembre de 1991, p. 213-243.
} 
populações diaguitas, a generalização do quéchua a partir do final do século XVI é claramente de origem colonial, e teve uma consequência que nos interessa diretamente: a comunicação entre as diferentes instâncias coloniais e os índios passou lentamente por um filtro linguístico duplo kakán-quéchua-espanhol.

Há algumas menções, especialmente no começo do período, de interpretação simples. Por exemplo, o caso da possessão, por parte do encomendero Juan de Abreu, dos índios do povoado de Amimaná, em 1592: Quando chegaram frente às autoridades [...] um índio chamado ynga e um índio chamado Panizay, cujas declarações ficaram registradas [...] por um escrivão (chamado Pedro Hernández) que sabia muito bem a língua diaguita $[. .$.$] o tal índio me entendeu bem. { }^{62}$

Mesmo assim, às vezes as declarações dos índios passavam por um itinerário mais longo. Em 1622, quando o bispo de Tucumán, Julián de Cortázar, visitou os vales Calchaquíes, por exemplo, as declarações foram reescritas "pela língua de Diego Laines, ladino na língua espanhola”, ou seja, neste caso - e era muito comum - , que falava quéchua e que era ladino na língua geral do inga "o qual Diego Laines interpretava dito lingua geral do ynga diziam os dois indios cuja língua entendem e eu falo".63

Ou seja, as declarações dos calchaquies, que se expressam em kakán, eram traduzidas pelo ladino Diego Laines para o quéchua, e logo eram passadas para o castelhano pelo escrivão, chamado Juan de Higueras. ${ }^{64}$ Por isso, no Tucumán e no restante do vice-reinado do Peru, foi feito todo o necessário para que o quéchua fosse considerado língua franca. Foram tomadas até medidas voluntaristas para estender seu uso entre índios e espanhóis-crioulos. O Sínodo de 1602 previa explicitamente, por exemplo, que os padres deveriam ensiná-la aos índios em quéchua "[...] porque grande parte dos índios torna-se ladino nesta língua"65 Por outro lado, as elites locais pressionavam para que as autoridades máximas recaíssem sobre alguém que já tivesse certa experiência na América - para não dizer um crioulo - e, para começar, que soubesse a língua geral. Neste sentido, o conselheiro de San Miguel de Tucumán pediu, em 1613: “[...] que o governador saiba a língua geral dos yngas, que muitos índios destas províncias entendem, especialmente os que trabalham em povoados e casas de espanhóis".66

Se as comunicações diretas eram relativamente limitadas, foi imposta uma "ladinização" (até o quéchua) dos índios incorporados à esfera colonial. Há muitos exemplos. Citaremos um caso limite, de tonada de posse dos índios - provavelmente "peças" ${ }^{67}$ — durante a fundação, no coração do vale de

\footnotetext{
${ }^{62}$ AGN, 1596, 14-09, "Posesión de los indios encomienda del pueblo de Amimaná a Juan de Abreu”.

63“Expediente de la visita que hizo el obispo de Tucumán, Doctor Julián Cortázar en el Valle Calchaquî”, In: Roberto Levillier (ed.), Papeles eclesiásticos del Tucumán, Madrid, ed. De Juan Pueyo, 1926, vol. 1, p. 315.

${ }^{64} \mathrm{AHPC}$, Escr. 1a, leg. 15, exp. 12, "Martin de Mojica contra Alonso Martin de Zorita sobre indios 1602". Foram encontrados varios casos similares no Tucumán, e não somente em terras diaguitas, por eemplo, a possessão da encomienda de Martín de Mojica, na jurisdição de Córdoba, faz-se também “en la lengua natural” havia "un muchacho de su servicio que conoce la lengua general del Piru que yo conozco".

${ }^{65}$ Citado por Estela Noli, "Indios ladinos del Tucumán colonial: Ios carpinteros de Marapa”, Andes, n. 12. 2001, p. 141.

${ }^{66}$ Roberto Levillier (ed.), Papeles eclesiásticos del Tucumán, Madrid, ed. De Juan Pueyo, 1926, vol. 1, p. 100-103, subrayado nuestro.

${ }^{67} \mathrm{Ou}$ seja, índios presos em "guerra justa" e depositados por um tempo determinado a serviço de um espanhol. Sobre esta prática, ver Gaston Doucet, "Sobre cautivos de guerra y esclavos indios en el Tucumán”, Revista de historia del derecho, n. 16, 1988, p. 59-152.
} 
Calchaquí do efêmero forte de Nossa Senhora de Guadalupe, em 1635. Esta se fez “[...] na língua geral do Peru, que entendem e falam os mencionados índios [...].$^{68}$ Contudo, os dois prisioneiros são "Luís Guallanchay, cacique principal do povoado de Guatungasta, e Diego, índio ladino do povoado de Fiambala”.

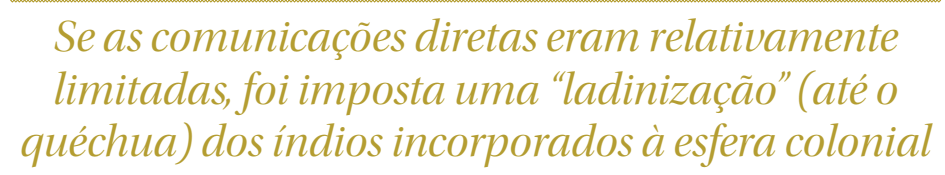

Como no caso já citado de Lorenzo Pisapanaco, tratava-se de índios diaguitas de encomienda, procedentes da jurisdição de La Rioja, refugiados no enclave rebelde calchaquí aproveitando da "Grande Rebelião", o que explicaria sua condição de ladinos. Era uma situação comparável com a dos índios pulares, outro segmento separado do grupo genérico inicial, chamado diaguita pelos espanhóis-crioulos, como consequência de sua submissão e incorporação precoce nos diferentes dispositivos econômicos e "civilizatórios" impostos pelas regras da convivência colonial. $\mathrm{O}$ fato de que um ou outro índio dominasse o quéchua era, muitas vezes, resultado do contato regular com os espanhóis, muito mais do que um sinal de uma antiga incorporação ao mundo dos incas, que impuseram a língua imperial em regiões longínquas e conflituosas. Esses contatos eram comuns durante os turnos de mita, que os levava a trabalhar nas cidades da província, nas terras de seu encomendero e, às vezes, até conduzir trens de mulas até o centro da Audiência de Charcas. A análise sincrônica da dominância da "língua geral do inca" por grupos que falam kakán, às vezes até parentes entre si, porém, separados pelo que se convém chamar de fronteira de guerra, demonstra, sem dúvida, o caráter determinante da relação colonial neste processo de aprendizagem. ${ }^{69}$ Da mesma forma, estudos sobre os grupos indígenas do lado oriental da Serra do Aconquija, controlada há muito tempo por encomenderos de San Miguel de Tucumán, demonstra o avanço do quéchua entre grupos que falavam kakán, o que se evidencia particularmente depois das desnaturalizações dos anos 1659-1665 e da reorganização de grupos retirados da área valliserrana na mesma região.

A visita do cura Vergudo Garnica, em 1685, demonstra claramente que eles tinham um conhecimento do quéchua notoriamente inferior, mantendo o

\footnotetext{
${ }^{8}$ Serviços do capitão don Gregorio de Luna y Cárdenas, AHPC-Escribanía II-4 n. 24; Aníbal Montes, Encomiendas de indios diaguitas documentadas en el archivo histórico de Córdoba, Córdoba, 1986, p. 10. ${ }^{69}$ Rodolfo Cruz estuda esta questão entre Tafíes e Amaichas, "La "construcción" de identidades étnicas en el Tucumán colonial: Ios amaichas y los tafies en el debate sobre su "verdadera" estructura étnica", In: Ana María Lorandi (comp.), El Tucumán colonial y Charcas, Buenos Aires, FFyL - UBA, 1997, T. II, p. 253-282.
} 
mesmo idioma materno. ${ }^{70}$ Estela Noli, em seu estudo sobre o povo de Marapa, que dependia diretamente de San Miguel de Tucumán, também mostra o abismo que separava os habitantes deste povoado, todos ladinos em quéchua, e os grupos recém-desnaturalizados, a quem lhes custava defender em uma situação na qual o uso do quéchua era estratégico. ${ }^{71}$

\section{o kakán, língua do inimigo/falando a língua do inimigo}

Se a expansão colonial do quéchua no Tucumán é parte de um processo geral, resta entender porque o kakán, que vimos ser uma língua veicular em nível regional quando da chegada dos espanhóis-crioulos, acabou sendo marginalizado e praticamente excluído das comunicações coloniais, a ponto de que, em meados do século XVII, os únicos que sabiam falar a língua, além dos índios, eram alguns missionários que viviam com eles. A explicação aponta, sem dúvida, para o estatuto simbólico desta língua em relação à posição de seus locutores na economia de vigilância da província. Ela firmou-se como a língua do inimigo e ficou geograficamente identificada com o enclave resistente calchaquí, pelo menos desde a primeira rebelião de 1562, que acabou com todas as cidades fundadas na área valliserrana. O que sem dúvida aumentou tais suspeitas foi o destino dos habitantes da cidade de Córdoba de Calchaquí: foram massacrados, exceto as crianças e as mulheres, que depois foram capturadas e espalhadas entre os indígenas. Algumas dessas crianças foram reconhecidas anos depois entre as "peças" levadas em cabrestos, depois das expedições militares, totalmente indianizadas. Tinham perdido sua língua materna, o que causou bastante desconforto entre os colonos da província. ${ }^{72}$

Falar o kakán podia até ser considerado como um marco de infidelidade, desde o momento em que sua prática não fazia parte do marco restrito das relações coloniais. O caso mais conhecido - porém, pouco documentado - é o do escândalo causado por Juan Baptista Muñoz, filho de um dos fundadores de Londres e de San Miguel de Tucumán, homem rico e poderoso, benfeitor da Companhia de Jesus, ${ }^{73}$ Juan Baptista Bernio. Muñoz tinha se refugiado nas montanhas e decidiu se refugiar com suas mulheres

\footnotetext{
${ }^{70}$ Larrouy, Documentos del Archivo de Indias para la historia del Tucumán, vol.1 Santuario de Señora del Valle, T.I, Buenos Aires, 1923, p. 360, et seq.

${ }^{71}$ Estela Noli, "Indios ladinos del Tucumán colonial: Ios carpinteros de Marapa", op. cit.. O quechua se estende de forma muito eloquente aos principais setores de atividade, e acaba contaminando o espanhol cotidiano, ao nomear categorías essenciais para a economía. O informe do Padre Juan Ximénez sobre os abusos dos pobleros das encomiendas de Londres denuncia, por exemplo, que: "Todos los días de la semana el poblero y camayo de cualquiera pueblo, al amanecer hace juntar a los curacas y fiscales los dichos indios e indias" para repartirles un guarço de lana para hila (citado en Laura Quiroga, "Las granjerías de la tierra: actores y escenarios del conflicto colonial en el valle de Londres (gobernación del Tucumán, 1607-1611)", Surandino Monográfico, segunda sección del Prohal Monográfico, vol. 2, n. 2, 2012 (en línea).

${ }^{72}$ Christophe Giudicelli, "El conquistador y su sombra. Silencios en la conquista del Tucumán (siglo XVI)", In: Christophe Giudicelli, Gilles Havard y Salvador Bernabéu Albert (eds), La indianización. Cautivos, renegados, "hommes libres" y misioneros en los confines de América (Siglos XVI-XIX), Madrid, Doce Calles, 2013, p. 137-160. ${ }^{73} \mathrm{AHT}$, protocolos, vol. 1, FS 1-2vta, "Don Juan Bautista Bernio alguacil del Santo Oficio de la Inquisición, hace donación a favor de la Compañía de Jesús de un solar de tierras que cae a la parte del río de la ciudad", San Miguel de Tucumán, 9-12-1588.
} 
indígenas em terras de guerra antes de construir uma vida com sua legítima esposa, segundos os princípios da moral cristã, como era exigido pelo governador da época, Juan Ramírez de Velasco.

Em um informe do fim de 1586, o governador estabeleceu que:

[...] o conselho municipal, vizinhos e outras pessoas da cidade de San Miguel de Tucumán desta administração me avisaram de um rapaz chamado Juan Baptista Muñoz, filho de Juan Baptista Bernio, que sem causa aparente saiu desta cidade a se meter entre os índios inimigos, e está fortalecido com eles [...] está com muita vontade de fazer mal e como ladino nas línguas dos naturais deste governo querer causar danos com eles aos espanhóis da cidade. ${ }^{74}$

Como se vê, o fato de falar a língua dos inimigos parecia ser um agravante, e colocava este indivíduo em uma situação de rebelião aberta, similar à dos "índios inimigos", ou seja, nesses anos toda a população de língua kakán que vivia nos altos vales do Tucumán, ${ }^{75}$ onde prisioneiros - e amantes - espanhóis corriam o risco de perder seu castelhano.

A nossa hipótese é que, além das relações pontuais de natureza administrativa, o gerenciamento da interlocução entre "calchaquíes" e espanhóiscrioulos tenha sido rapidamente inserido na política de pacificação e submissão, reservada a dois tipos de especialistas: militares e religiosos por motivos diferentes, porém, em partes convergentes, até porque em todas as zonas de conquista os missionários chegaram com a tropa, e as missões no prolongamento das "entradas". No nosso caso, o primeiro jesuíta vindo do Peru para conhecer alguns indígenas que falavam kakán, o já mencionado Alonso de Barzana, não o fez como missionário, mas como capelão das tropas vindas de Salta para uma campanha particularmente difícil nos vales, que durou vários meses. ${ }^{76}$ Foi também sob a instância das autoridades civis e eclesiásticas, e sob a proteção dos soldados dessa mesma cidade, que a Companhia pôde desenvolver seu trabalho missionário entre os índios, primeiro em forma

\footnotetext{
74“Comisión dada por el gobernador Don Juan Ramírez de Velasco al capitán Hernán Mexia Miraval para que fuese a prender a Juan Bautista Muñoz 24-1-1586", In: Roberto Levillier, Probanzas de méritos y servicios de los conquistadores, Madrid, Sucesores de Rivadeneyra, vol. 2, 1919-1920, p. 602. Subrayado nuestro. ${ }^{75}$ Além de San Miguel, a única cidade que tinha sido fundada era Salta, em 1582, porém, segundo Rámirez de Velasco, "aunque ha cinco años que se pobló, no le sirve indio, y se sustenta con grandísimo trabajo, por no haber más de un fuerte en que están 30 o 35 soldados, con solo la esperanza de que se ha de salir á hacer la guerra, sin llevar salario ni gaje de S. M., el teniente y los soldados, á cuya causa pasan mucha necesidad”, “Carta del gobernador Don Juan Ramírez de Velasco al virrey del Perú, conde del Villar, O4-061587, In: Roberto Levillier, Gobernación del Tucumán, Papeles de gobernadores en el siglo XVI, vol. 2, Madrid, Juan Pueyo, 1920, p. 209-213.

76“Carta del gobernador Juan Ramírez de Velasco a S.M., 13-03-1588”, In: Roberto Levillier, Gobernación del Tucumán, Papeles de gobernadores en el siglo XVI, vol. 2, Madrid, Juan Pueyo, 1920, p. 235-239.
} 
de missões esporádicas e, em seguida, com a presença permanente em duas ocasiões: os períodos de 1617-162477 e 1643-1658.

\section{Altos e baixos linguísticos da evangelização}

Os missionários tinham interesse técnico e profissional em adquirir o conhecimento do kakán: deviam ensinar a Boa Nova aos índios e convencê-los a abraçar a vida seguindo os princípios da "polícia cristã".

Como vimos, o trabalho linguístico dos missionários em terras diaguitas parece corresponder à excelência da qual tanto falam os historiadores da Companhia. O famoso padre Barzana, muito conhecido como o apóstolo de Tucumán, e seu companheiro Pedro de Añasco tinham escrito, desde os primeiros anos, uma catequese e um vocabulário com o objetivo de facilitar o trabalho missionário, e que pareciam já surtir efeito em 1594:

Um só padre começou a casar, confessar, catequizar nela; mesmo que muito principiante, batizou muitas pessoas, e casou e confessou muitos outros que, em toda sua vida, sabiam o que era se confessar. ${ }^{78}$

Nesses anos, a prática se orientava no Tucumán, e em todas as terras com missionários da Companhia fazia a administração multitudinária dos sacramentos, sem que os padres se preocupassem demais em entender bem as confissões, ou que os índios pudessem apreciar as sutilezas do mistério da eucaristia. ${ }^{79}$ Sem dúvida, apesar desses princípios promissores, os progressos desses obreiros em kakán foram bem mais tímidos.

A Carta Anua de 1609 menciona que o "padre Horacio [Morelli] progride com a língua e com muito cuidado catequiza e fala com ela [...]". Porém, apesar de a Companhia ter se estabelecido em duas residências fixas entre 1617 e 1624, a Carta Anua de 1626-27 ainda fala do trabalho de aprendizagem dos missionários: "[...] aplica-se para aprender a língua chaca e relembrar um catecismo breve que temos feito para que todos catequizemos [...]". ${ }^{81}$ Dez anos depois, em

\footnotetext{
$\overline{{ }^{7} M a r i ́ a ~ F l o r e n c i a ~ A m i g o ́ ~ p r o p u s ~ o ~ a n o ~ d e ~} 1622$ para o primeiro abandono das doutrinas jesuitas, El desafío de Calchaquí. Un puñado de jesuitas entre un mar de indios. La intervención de la Compañía de Jesús en el Valle Calchaquí (siglos XVI-XVII). Tesis (Licenciatura en Ciencias Antropológicas) - Facultad de Filosofía y Letras, Universidad de Buenos Aires, 2000. Um informe do provincial Pedro de Oñate, de 1623, afirma que a residencia de Calchaquí "tiene cinco padres y un hermano. Dales su Mgtd para su sustento 1,200 pesos de renta con que apenas se puede sustentar el dicho numero. No tienen iglesias ni ornamentos bastantes ni alhajas sino mucha pobreza". ARSI, Paraquaria 4-1, F. 89 v. Outro informe adjunto ao catálogo trienal de 1626 pelo Provincial Nicolás Mastrilli Durán reporta que o colégio de Salta se encarrega das "misiones de Calchaquí, de las que les hemos salido por falta de sustento" (ARSI, Paraquaria 4-1, F 110 f). Do documento citado na nota 12, pode-se inferir que a missão permanente desapareceu provavelmente em 1624.

${ }_{78 “}$ Carta do padre Alonco de Barçana ao p. Juan Sebastián, provincial 1594, 08-09 (de Assunção)", Monumenta Peruana, T.V., Roma, institutum historicum Societati lesu, 1970, p. 568-580, et seq.

${ }^{79}$ Os batismos multitudinários eram praticados também no mesmo momento na nova provincia dos Tepehuanes, no Norte da Nova Espanha. Ver informes do padre Jerónimo nas Cartas Anuas de 1596 y 1597. Vicente García Torres (ed.), Documentos para la historia de México, México, 1854-1857, 3 vol.

80 Paraquaria, 8, ff 30f-32 f, reproducido en “Documentos para la historia de Argentina”, Buenos Aires, Instituto de Investigaciones Históricas Dr. Emilio Ravignani, FFyL, UBA, 1927-1929, T. 19, p. 75-77.

81“Documentos para la historia de Argentina", Buenos Aires, Instituto de Investigaciones Históricas Dr. Emilio Ravignani, FFyL, UBA, 1927-1929, p. 178-183.
} 
meados dos anos 1630, o nível parece ter piorado. Os missionários nem tentam dar sermões ou decifrar as confissões; nem podem se comunicar, "[...] sendo às vezes preciso usar um dos intérpretes de diferentes línguas por não entender a sua própria, os Padres assim para instruí-los e para torná-los capazes de confessar".82

Até a mensagem apostólica difundida pelos capelães jesuítas durante as campanhas de "pacificação" tinha de passar por um ou vários intérpretes:

[os padres] instruíram bem a todos nas coisas da fé, utilizando bons intérpretes, já que sua língua era muito complicada, e porque muitos não entendiam aquela que geralmente falam os padres. ${ }^{83}$

A pergunta que se poderia fazer a esta altura é por que os jesuítas, ao contrário de sua reputação quando se trata de aprender idiomas indígenas ${ }^{84}$ (e não somente no Novo Mundo), deixaram impressão tão pobre neste cenário tucumano. A desculpa da dificuldade do kakán não funciona, "língua ([...]) estranhamente bárbara, com pronúncia duríssima". ${ }^{85}$ A explicação é outra completamente diferente, e remete ao menos a dois fatores: a delicada posição da Companhia nas primeiras décadas do século XVII, devido à sua oposição radical ao serviço pessoal, e a situação ideológica já comentada do kakán.

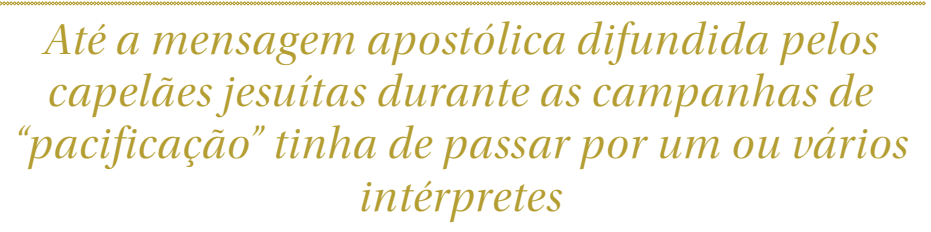

Quanto ao primeiro fator, está claro que a posição dos jesuítas da recente província do Paraguai contra o serviço pessoal não fez surgir em seus religiosos um amor incomensurável por parte dos primeiros interessados em seu sucesso, ou seja, os encomenderos, que detinham a realidade do poder no Tucumán. Os jesuítas criticaram duramente o serviço pessoal, generalizado e regularizado no Tucumán desde as normas instauradas em 1576 pelo governador Gonzalo de Abréu, ${ }^{86}$ incluídas antes das novas, editadas pelo inspetor e ouvidor da Audiência de Charcas, Francisco de Alfaro. Os Pareceres extremamente críticos apresentados em 1609 pelo teólogo da Companhia, Juan

\footnotetext{
${ }^{82}$ Anua de 1635-37, “Documentos para la historia de Argentina”, T. 20, p. 400-415

${ }^{83}$ Anua de 1632-1634, Cartas Anuas de la provincia jesuitica del Paraguay, Academia Nacional de la Historia, Buenos Aires, 1990, p. 53.

${ }^{84}$ Uma reputação amplamente mascarada, se não magnificada em várias regiões. Para o Norte do México, ver Bernd Hausberger, "Política y cambios lingüísticos en el noroeste jesuítico de la Nueva España", Relaciones, n. 78, 1999, p. 59-77.

${ }^{85}$ Anua de 1632-1634, Cartas Anuas de la provincia jesuítica del Paraguay, Academia Nacional de la Historia, Buenos Aires, 1990, p. 72-73

${ }^{86} \mathrm{O}$ texto das normas se encontra reproduzido em Levillier, Gobernación del Tucumán, Papeles de gobernadores en el siglo XVI, vol. 2, Madrid, Juan Pueyo, 1920, T. 2, p. 32-45.
} 
Pérez de Menacho, foram assinados pelos missionários do Tucumán: Horacio Morelli, Luís de Hoyos e Juan Darío. ${ }^{87}$ As Cartas Anuas redigidas na década de 1610 pelo padre Diego de Torres Bollo condenam, com termos muito severos, a cobiça e a crueldade dos encomenderos, ${ }^{88}$ o que causou um desconforto com parte das elites locais. Assim, tornou-se insustentável a permanência na sua Residência de Calchaquí, finalmente abandonada em 1624, após um informe do bispo Julián de Cortázar que, por fim, desacreditou a ação dos missionários, aliando-se à posição dos encomenderos. ${ }^{89}$

Acreditamos que o segundo fator foi, porém, mais importante para explicar o escasso progresso dos jesuítas entre os calchaquíes e sua dificuldade em aprender sua língua. Tratando-se da língua do inimigo interior, confinada geográfica e politicamente, os missionários parecem ter se dedicado - ou ter sido limitados - antes de tudo às suas tarefas políticas. Um cuidado explicitado desde o início: foram chamados "para pacificar e reduzir os índios" ${ }^{90}$ Depois dos quase 15 anos que durou a Grande Rebelião, foi necessário começar do zero. Assim, escolheram privilegiar a reinstalação das missões permanentes na região valliserrana, enviando quatro padres para as antigas doutrinas de San Carlos e Santa Maria. O objetivo contemplava aspectos religiosos, supostamente, mas deve-se destacar que a iniciativa foi novamente tomada pelas autoridades civis e pelo bispo do Tucumán, Fray Alonso Maldonado, movidos por inquietações mais temporais de vigilância e de pacificação mais suave. O bispo estranhou, com razão, o notável despreparo dos jesuítas, especialmente em relação à língua: "[...] quando a Companhia de Jesus foi solicitada a voltar ao vale; não havia ninguém que entendesse a língua, o que era raro".11

Para tanto, novos obreiros tiveram de ser formados rapidamente. Para isso, nada melhor que outro tipo de especialista: os padres destinados ao ofício se estabeleceram primeiro no forte do Pantano, uma espécie de megarredução militarizada para onde tinham sido deportados e concentrados os índios diaguitas, considerados mais culpados no final dos anos $1630 .{ }^{92} \mathrm{Ali}$, para sua aprendizagem e ministério, os missionários aprendizes puderam contar, entre 1639 e 1643, com o conhecimento bruto de um personagem que conhecia bem a língua desses presos de guerra, por razões óbvias, e era Antonio Calderón: ele

\footnotetext{
${ }^{87} \mathrm{AGN}$, Fondo Biblioteca Nacional, n. 5621(leg.840), “Pareceres sobre las principales ordenanzas del gobernador del Tucumán Gonzalo de Abreu, relativas al servicio personal de los indios de aquella gobernación”.

${ }^{88}$ Anua de 1613, In: Documentos para la historia Argentina, T. 19, Buenos Aires, Instituto de Investigaciones Históricas Dr. Emilio Ravignani, FFyL, UBA, 1927-1929, p. 197.

89"Expediente da visita do bispo de Tucumán, Doctor Julián Cortázar ao Vale de Calchaquí, 02-10-1622, 11-1622", Roberto Levillier, (ed.), Papeles eclesiásticos del Tucumán, Madrid, ed. De Juan Pueyo, 1926, vol. 1, p. 308-323. ${ }^{90}$ Anua de 1624, Documentos para la historia Argentina, T. 19, p. 75.

${ }^{9}$ Carta del obispo Fray Melchor de Maldonado, 13-09-1658, In: Larrouy, Documentos del Archivo de Indias para la historia del Tucumán, vol. 1 Santuario de Señora del Valle, T.I, Buenos Aires, 1923, p. 202.

${ }^{92}$ Ana María Lorandi y Sara Sosa Miatello, "El precio de la libertad. Desnaturalización y traslados de indios rebeldes en el siglo XVII", Memoria Americana, vol. 1, n. 1, 1991, p. 7-28.
} 
era o responsável militar pelo forte em questão. ${ }^{93}$ Hernando de Torreblanca, que ainda não era o grande intérprete que achava que era, faz uma sincera homenagem ao seu maestro na obra Relación:

\begin{abstract}
Neste tempo conseguimos um grande tradutor chamado Antonio Calderón, que nos serve de intérprete, revisa o vocabulário da língua calchaquí, comparando-o com os vocábulos da língua que se fala aqui, que varia em muito na pronúncia, ainda que em substância sejam similares. ${ }^{94}$
\end{abstract}

Contudo, o aprendizado do diaguita do Vale Calchaquí aparentemente não era tão fácil. Poucos meses antes de ser instalado em San Carlos, Torreblanca se queixava da dificuldade que ainda sentia para se comunicar:

[...] os índios não querem muito que nós aprendamos sua língua. É também difícil de criar um método; ainda que os primeiros padres tenham trabalhado, como mostram seus escritos, é coisa muito difícil. ${ }^{95}$

Seria necessário esperar a década seguinte para que a Companhia pudesse vangloriar-se, por fim, dos dotes de seus representantes em terras calchaquíes, que "aprenderam perfeitamente a língua bárbara e difícil" 96 - a falta de qualquer resultado espiritual. Definitivamente, Torreblanca teve que esperar a chegada de Pedro Bohórquez para mensurar seu talento como tradutor" durante as negociações mantidas entre as diferentes partes. Paradoxo cruel: foram precisamente essas negociações que precipitaram o fim da missão e redirecionaram o solitário missionário bilíngue a tarefas castrenses.

\title{
Conclusões
}

Falar a língua do inimigo e ser finalmente o perito mais procurado por próprios e alheios permitiu ao missionário acompanhar seus locutores até o desaparecimento dessa língua. Após serem vencidas e dispersas pelos quatro cantos do Tucumán e do Rio da Prata, as populações diaguitas, por motivos difíceis de determinar com certeza , mas que certamente têm ligação com a economia simbólica das relações coloniais com as necessidades nascidas de sua nova condição de vencidos, acabaram perdendo seu idioma. Reduzidos em estabelecimentos coloniais - fazendas ou povoados indígenas - onde conviveram não só com outros ladinos de diversas origens, mas também, e cada vez mais, com presos

\footnotetext{
${ }_{93}$ Outros documentos descrevem nos mesmos termos as atitudes deste personagem: "declaração de Antonio Calderón, chefe do forte do Pantano, diz que conhece muito bem esses índios porque é crioulo nascido e criado na cidade de San Juan de la Ribera, e que é testemunha de ser o melhor orador da língua dos ditos índios diaguitas. Aníbal Montes, "El gran alzamiento diaguita", Revista del Instituto de Antropología, Universidad del Litoral, Rosario, n. 1, 1961, "Probanza para la entrada a Malfín”, p. 152.

${ }^{94}$ Hernando de Torreblanca, Relación Histórica de Calchaquí, Buenos Aires, AGN, 1999. [1696], p. 98.

${ }_{95}^{9}$ Pablo Pastells, "Carta del Provincial de la Cia de Jesús Fco de Lupercio de Zurbano a SM 1644, $19-12$ (desde Bs Aires)", Historia de la Compañía de Jesús en la provincia del Paraguay, Madrid, Victoriano Suárez, 1912, vol. 2. t. 2. p. 96-101

96“Carta Anua 1653-1654", In: Jaime Cortesão, Manuscritos da coleção de Angelis, t. II: Jesuítas e bandeirantes no Itatim (1596-1760), Rio de Janeiro, Biblioteca Nacional do Rio de Janeiro, 1952, p. 139
} 
moscovíes e tobas capturados nas tribos organizadas no Chaco, tiveram de se apoiar em novas formas comuns de expressão. Com o quéchua, sem dúvida, cada vez mais próximo do espanhol, o kakán ocupou cada vez menos espaço.

Uma investigação mais detalhada é necessária para seguir de fato esta evolução. Um bom indicador pode ser o estudo sistemático dos arquivos relacionados às encomiendas e dos arquivos judiciais posteriores às campanhas de desnaturalização, para entender que tipo de tratamento estava reservado aos desnaturalizados. Uma análise rápida às atas da visita do ouvidor Luján de Vargas às encomiendas de Tucumán, ${ }^{97}$ La Rioja e Jujuy, ${ }^{98}$ onde muitos dos calchaquís tinham sido "reduzidos", visita quase contemporânea à escrita da Relación Histórica de Calchaquí, levanta dois comentários. Primeiramente, esses índios aparecem já como "calchaquís", sem precisão sobre o lugar exato de sua procedência. Em segundo lugar, mesmo com a nomeação da visita de dois intérpretes - o escrivão Lorenzo Pinto e o protetor dos índios, Diego de Salazar y Benavidez (originario de La Rioja) —, não está indicado em nenhum lugar qual é o idioma que falam. Pois bem, em vários casos são interrogados juntamente índios calchaquís e mocovies ${ }^{99}$ que sabemos que não falavam a mesma língua. Vale perguntar como, nessas circunstâncias, esses índios puderam transmitir suas queixas aos magistrados. Mesmo que seja difícil determinar com certeza, está claro que este tipo de dispositivo legal influenciou a adoção, por parte dos vencidos, das línguas de comunicação colonial. Ao passar de língua do inimigo para língua do vencido, o kakán perdeu paulatinamente seu marco de existência autônoma.

\footnotetext{
${ }^{97}$ Estela Noli, "Pueblos de indios, indios sin pueblos: los calchaquíes desnaturalizados en la visita de Luján de Vargas de 1693 a San Miguel de Tucumán”, Anales Nueva Época, 6, Göteborg, 2003, p. 330-363.

${ }^{98}$ Roxana Boixados y Carlos Zanolli, La visita de Luján de Vargas a las encomiendas de La Rioja y Jujuy (1693-1694), Quilmes, UNQ, 2003.

${ }_{99}^{9}$ Por exemplo, comparecem em La Rioja, no dia 2 de julho de 1693, Juan Calchaquí e Agustín Mocoví, Ibidem. p. 70
} 